\title{
Left-Wing Media Politics and the Advertising Tax. Reflections on Astra Taylor's Book "The People's Platform: Taking Back Power and Culture in the Digital Age"
}

\author{
Christian Fuchs
} University of Westminster, London, UK, christian.fuchs@uti.at, http://www.uti.at,
@fuchschristian

\begin{abstract}
This article is a reflection on Astra Taylor's book "The People's Platform: Taking Back Power and Culture in the Digital Age". It especially focuses on the media reform suggestions the book makes and provides further thoughts and data that go beyond Taylor's book on the question of how feasible an advertising tax and a participatory media fee are.
\end{abstract}

Keywords: capitalism, digital media, advertising, Astra Taylor, advertising tax, participatory media fee

Astra Taylor: The People's Platform: Taking Back Power and Culture in the Digital Age. London, Fourth Estate, 2014, 288 pages. ISBN 978-0-00-752559-1

The author, documentary filmmaker and activist Astra Taylor wrote a book about the social media's ideological mythologisation and inequality in the Internet age. The People's Platform: Taking Back Power and Culture in the Digital Age (Taylor 2014) promises perspectives on alternative net politics and is therefore a good opportunity to reflect on left-wing political strategies and demands in the time of social media.

One of the book's strengths is that Taylor not just formulated a critique of the neoliberal ideology spread by Internet optimists such as Chris Anderson, Richard Florida, or Kevin Kelly, but that she also questions the openness ideology advanced by digital social democrats such as Lawrence Lessig, Yochai Benkler, or Clay Shirky. Taylor describes how representatives of the openness ideology that demands access to culture and communication technologies without payment sit in the same boat with the advertising industry and corporations such as Google and Facebook, which strengthens the culture of advertising, marketing, public relations, sponsorship, and branding on the Internet. However, the book somehow underemphasises the other side of the antagonism between the capital faction of the media content industry that commodifies content and the capital faction of the advertising industry that sells audiences and users: Cultural producers who criticise the free access to culture as undermining their possibilities for earning a living, can easily find themselves in one political boat with the media content industry that exploits artists and makes demands for strong intellectual property rights, Internet surveillance, and censorship.

How should an adequate left-wing political answer to the antagonism between the media content industry, the advertising industry, artists and users look like? It is doubtful whether the political left can and should appropriate the notion of sustainable culture that Astra Taylor brings into play. She by this term means the demand for publicly funded culture. The problem is that not just the green movement, but also corporations fetishise the notion of sustainability in order to demand "sustainable" growth of their profits.

Among Taylor's suggestions for the strengthening of public culture are, for example, shortening the duration of copyright (170), fees for the limitation of the reuse of culture (171), the introduction of an initial copyright on culture that expires after a limited time so that cultural goods are turned into public goods (171), communal broadband initiatives (226), publicly funded digital archives (220), advertising-free search engines (222), alternatives to iTunes and Netflix that are operated as co-operatives (222), the introduction of press subsidies in the USA (226-227), the public funding of community centres as well as local book shops and 
movie theatres $(175,217,228)$, the collection of taxes that global tech firms such as Google, Apple and Amazon that avoid paying (229), and the introduction of an advertising tax (229).

Overall these suggestions remain enumerative and unspecific. Missing is for example a more detailed planning of how new taxes could look like, which also requires a stringent justification on the theoretical level that employs the critique of political economy as its approach. An example in this context is the need to draw political conclusions from an engagement with digital labour theory. However, Taylor considers this theory to be "slightly esoteric" (235) and therefore ignores it. Her book is however a welcome opportunity to formulate further ideas on strategies for left-wing media and net politics.

States usually make companies pay capital taxes and social security contributions for employees. The Marxist theory of audience and digital labour (see the explanations in my books Digital Labour and Karl Marx, as well as Culture and Economy in the Age of Social Media; Fuchs 2014, 2015) assumes that the economic value of advertising-financed media is not simply created by these organisations' wage-labour, but also by their audiences respectively users who create attention and data that are sold as commodity to advertising clients. Advertising corporations, including Google and Facebook, outsource value creation to consumption workers, whereby they increase their profitability and keep the number of their employees low (Fuchs 2015). An advertising tax can be seen as a kind of tax on the exploitation of audience and digital labour. It is comparable to social security payments that companies pay to the state for their regular employees.

According to data, the global media revenues had a compound annual growth rate between $5.9 \%$ and $6.5 \%$ in the years from 2010 until 2013 (McKinsey 2014; table 1). They amounted to around US\$1.6 trillion in 2013 (McKinsey 2014). Advertising revenues made up US $\$ 461.0$ billion or $29.6 \%$ of the total global media revenues. This sum accounts for approximately $0.6 \%$ of the worldwide gross domestic product (source of GDP data: IMF World Economic Outlook Database).

\begin{tabular}{|l|l|}
\hline Forms of Advertising & Shares of Global Advertising Revenue \\
\hline Digital & $38.0 \%$ \\
\hline Television & $35.1 \%$ \\
\hline Newspapers & $10.5 \%$ \\
\hline Outdoor & $6.5 \%$ \\
\hline Audio & $5.2 \%$ \\
\hline Magazines & $3.2 \%$ \\
\hline Computer games & $1.0 \%$ \\
\hline Cinemas & $0.5 \%$ \\
\hline
\end{tabular}

Table 1: Specific forms of advertising accounted for the following shares of the global advertising revenue (data source: McKinsey 2014).

Advertising expenditures increased by $25.8 \%$ in the time period from 2009 until 2013 (Ofcom 2014). The average annual compound growth rate was during this period $18.9 \%$ for Internet advertising and $-1.35 \%$ for newspaper advertising (Ofcom 2014). Companies tend to see targeted online advertising as a more secure investment, although it is unclear how effectively it really is. Radio and newspapers have a very high share of advertising financing, the Internet and television also a relatively high one (table 2). Media advertising gives companies the possibility to exercise censorship by exerting financial pressure. 


\begin{tabular}{|l|l|l|l|l|l|l|}
\hline & TV 2013 & $\begin{array}{l}\text { Radio } \\
2013\end{array}$ & $\begin{array}{l}\text { Newspa- } \\
\text { pers 2013 }\end{array}$ & $\begin{array}{l}\text { 10 leading } \\
\text { web platforms }\end{array}$ & $\begin{array}{l}\text { Cinema } \\
2013\end{array}$ & $\begin{array}{l}\text { Computer } \\
\text { games } \\
2013\end{array}$ \\
\hline Total revenues & $254 \mathrm{bn} £$ & $28 \mathrm{bn} £$ & $152.8 \mathrm{bn} \$$ & $166.7 \mathrm{bn} \$$ & $37.2 \mathrm{bn} \$$ & $70.0 \mathrm{bn} \$$ \\
\hline $\begin{array}{l}\text { Advertising } \\
\text { share }\end{array}$ & $40.6 \%$ & $78.6 \%$ & & $44.1 \%$ & $6.2 \%$ & $4.0 \%$ \\
\hline License fees & $9.4 \%$ & $14.3 \%$ & $53.0 \%$ & & & \\
\hline $\begin{array}{l}\text { Subscription } \\
\text { fees }\end{array}$ & $50.0 \%$ & $7.1 \%$ & & & & \\
\hline
\end{tabular}

Table 2: Advertising financing and global media revenues

Data sources: TV, radio: Ofcom 2014; newspapers, cinema, computer games: McKinsey 2014; WWW: alexa.com (accessed on December 27, 2014), SEC filings 2013 (forms 10-K, 20-F, F-1A: Google, Facebook, Yahoo, Baidu, Amazon, Alibaba, Twitter, Tencent), Wikimedia Financial Statement June 30, 2014 and 2013, Tencent 2013 Annual Report

Viktor Orbáns' right-wing government introduced an advertising tax and other forms of corporate taxation in Hungary in order to strengthen the position of national capital. The right-wing appropriation of the advertising tax shows the importance to think about advertising as a global phenomenon that is part of the production process and stands in the context of the critique of the totality of capitalism and the political demand for increasing the taxation of capital. An advertising tax exists for example in Austria, Italy, Greece, Belgium, Estonia, Croatia, Sweden, Portugal, and Romania. Internet advertising tends to be excluded from this tax, although it has a rising share in total advertising. The consequence is that existing advertising taxes are rather ineffective.

\begin{tabular}{|l|l|l|l|l|}
\hline & $\begin{array}{l}\text { Advertising revenue } \\
2014 \text { (Austria: } \\
2013)\end{array}$ & $\begin{array}{l}\text { Number of } \\
\text { households }\end{array}$ & $\begin{array}{l}\text { Advertising tax } \\
\text { of } 10 \%\end{array}$ & $\begin{array}{l}\text { Media cheque per } \\
\text { household }\end{array}$ \\
\hline Germany & 19.0 billion $€$ & 39.9 million & 1.9 billion $€$ & $48 €$ \\
\hline Austria & 3.2 billion $€$ & 3.7 million & 317 billion $€$ & $86 €$ \\
\hline UK & 19.7 billion $€$ & 26.4 million & 1.97 billion $€$ & $75 €$ \\
\hline USA & 125.93 billion $€$ & 115.6 million & 12.6 billion $€$ & $109 €$ \\
\hline
\end{tabular}

Table 3: Example calculations for an advertising tax.

Data sources: WARC, Statistisches Bundesamt, Statistik Austria, ONS, US Census Bureau

Table 3 shows that a tax on advertising expenditures can fund a media cheque that amounts to 50-100 Euros per household. Participatory budgeting could be used for providing such a cheque to households with the obligation that they have to donate the amount to noncommercial media organisations (Fuchs 2015). The participatory media fee is one of the possible reforms that could strengthen public and alternative media (Fuchs 2015). It can be designed in different ways, so the data I provided should just be seen as an example calculation. Different models are imaginable. Astra Taylor's book is a good occasion for thinking about political strategies and demands of left-wing media politics.

\section{References}

Fuchs, Christian. 2015. Culture and Economy in the Age of Social Media. New York: Routledge.

Fuchs, Christian. 2014. Digital Labour and Karl Marx. New York: Routledge.

McKinsey. 2014. McKinsey Global Media Report 2014. Accessed January 15, 2015. http://www.mckinsey.com/ /media/mckinsey/dotcom/client service/media\%20and\%20entertainme nt/pdfs $/ 6232 \% 20$ global media trends\%20report 2014 industry\%20overview v8 online.ashx.

Ofcom. 2014. Ofcom International Communications Market Report 2014. Accessed January 15, 2015. http://stakeholders.ofcom.org.uk/binaries/research/cmr/cmr14/icmr/ICMR_2014.pdf. 
Taylor, Astra. 2014. The People's Platform: Taking Back Power and Culture in the Digital Age. London: Fourth Estate.

\section{About the Author}

Christian Fuchs

is professor at the University of Westminster's Communication and Media Research Institute and the Centre for Social Media Research. He is editor of the journal tripleC: Communication, Capitalism \& Critique (http://www.triple-c.at) and author of around 250 publications in the field of the political economy and critical theory of media, communications and the Internet. http://fuchs.uti.at, @fuchschristian. 